Adam R. Bartnicki

Uniwersytet w Biatymstoku

\title{
WYBORY DO DUMY PAŃSTWOWEJ ROSJI 1993-2011
}

\section{Wstęp}

Polityczna praktyka współczesnej Rosji wskazywała na stałe, jednak z reguły nieudane, próby budowania grup i obozów opozycji zdolnych do podjęcia roli alternatywy wobec dominującego reżimu politycznego. Jedną z przyczyn takiego stanu rzeczy był bipolarny układ sił w ZSRR przełomu lat 80. i 90. XX w., który nie sprzyjał tworzeniu się dalszych alternatyw, sprowadzając polityczne wybory do dychotomii „demokratyczny” - ,antydemokratyczny”. 'Wiązało się to z dezorientacją znacznej części elit, która często odnajdywała się w przypadkowym otoczeniu, utrudniającym budowanie własnej tożsamości politycznej. Problem ten był potęgowany przez koniunkturalizm poszczególnych polityków, jak też partii i grup społecznych. Elementem radykalnie osłabiającym polityczną rolę parlamentu było też przekonanie, że to na Kremlu, ${ }^{2}$ a nie w parlamencie znajdują się realne uprawnienia władcze. Do pewnego stopnia wynikało to z zapisów konstytucji, jednak w gruncie rzeczy parlament zrobił bardzo niewiele, żeby to zmienić. W tym układzie celem większości liderów ugrupowań parlamentarnych była walka o prezydenturę, a nie reformę systemu politycznego i zmianę konstytucji. Funkcjonujące uprawnienia prezydenta mogły być dla opozycji korzystne przy założeniu przejęcia tego urzędu. Koncentrowanie głównych sił ugrupowań parlamentarnych na wyborach prezydenckich sprawiało, że ewentualne sojusze musiały być nietrwałe. Zbyt wiele było prywatnych ambicji i celów. Sytuację tę znakomicie umiał natomiast wykorzystywać Borys Jelcyn, który stosując metodę „,dziel i rządź” bardzo długo i przeważnie skutecznie kontrolował opozycję. Cieniem na rosyjskiej opozycji najbardziej położył się więc sam cel jej politycznych działań, którym nie było stworzenie alternatywy dla programu realizowanego przez Kreml, ale alternatywy dla samej władzy.

\footnotetext{
1 В. Гельман, Правящий режим и проблема демократической оппозиции в постсоветском обществе, s. 3 wydruku z http://www.igpi.ru/monitoring/1047645476/jan1994/Analiz.htm (data dostępu: 03.02.2004 r.). Kreml jako obóz polityczny skupiony wokół prezydenta.
} 
Niniejsza analiza ma na celu pokazanie przebiegu i rezultatów wyborów do Dumy w latach 1993-2011, a także niektórych zmian prawa wyborczego oraz otoczenia politycznego, które przyczyniały się do marginalizacji przez Kreml opozycji. W latach 1990-2011 opozycja trzykrotnie zdołała utworzyć w miarę jednolity front walki z reżimem. Po raz pierwszy w latach 1990-1991, kiedy to doszło do prawdziwego zjednoczenia sił liberalnych i nacjonalistycznych pod przywództwem Jelcyna dążących do obalenia komunizmu, po raz drugi w latach 1992-1993, tj. w okresie sporu konstytucyjnego, w którym naprzeciwko siebie stanęli niedawni sojusznicy w walce o wolną Rosję, i po raz trzeci w latach 1998-1999 podczas wszczętej wobec prezydenta procedury impeachmentu. Po 2000 r. w Rosji można obserwować zjawisko „reglamentowanej opozycyjności”, w której Kreml decyduje o charakterze, sile, jakości i potencjale „opozycji”. Po wyborach 2007 r. opozycja parlamentarna w Rosji została praktycznie wyeliminowana poprzez zmiany w procedurze wyborczej oraz ekspansywną propagandę kierowaną do Rosjan za pomocą kontrolowanych przez rządzącą ekipę środków masowej informacji.

\section{Wybory do Dumy - 12 grudnia 1993 r.}

Dnia 21 września 1993 roku prezydent Borys Jelcyn wydał dekret o rozwiązaniu Zjazdu Deputowanych Ludowych i Rady Najwyższej. Jednocześnie zarządził nowe wybory parlamentarne i referendum konstytucyjne na dzień 12 grudnia 1993 roku. Według projektu nowej konstytucji w Rosji miał powstać dwuizbowy parlament - Zgromadzenie Federalne - składający się z Dumy Państwowej (izby niższej) i Rady Federacji (izby wyższej).

Równocześnie z pracami nad nową konstytucją trwała krótka i nie do końca uczciwa kampania wyborcza. Toczyła się ona wedhug nowej ordynacji. Elekcja do liczącej 178 deputowanych izby wyższej - Rady Federacji - miała odbywać się według ordynacji większościowej. Kandydaci byli wybierani w 89 okręgach dwumandatowych pokrywających się z granicami podmiotów Federacji Rosyjskiej. W wyborach do liczącej 450 deputowanych izby niższej - Dumy Państwowej obowiązywała ordynacja proporcjonalno-większościowa. Połowa miejsc w izbie niższej (225) była obsadzona kandydatami z list federalnych zgłoszonych przez partie i bloki polityczne, którym udało się przekroczyć 5-procentowy próg wyborczy (proporcjonalnie do liczby zebranych głosów). Walka o drugą połowę miejsc w Dumie toczyła się w okręgach jednomandatowych - zgodnie z zasadami ordynacji większościowej - wygrywał ten kandydat, który dostał więcej głosów (frekwencja wyborcza nie mogła być mniejsza niż 25 proc. uprawnionych do głosowania).

Spośród 21 partii i ugrupowań, którym udało się zebrać w terminie wymagane 100 tys. podpisów pod listami kandydatów, ośmiu Centralna Komisja Wyborcza odmówiła rejestracji list, co było równoznaczne z wykluczeniem z wyborów. 
Przyczyny odmowy były różne. Niektóre ugrupowania dostarczyły listy zawierające mniej podpisów, niż wymagała ordynacja. Dwie partie same wycofały swe listy, wzywając wyborców, by głosowali na demokratów. „Rosyjski Związek Ogólnonarodowy" Siergieja Baburina spełnił, co prawda, wszystkie warunki, ale naruszył zasadę, w myśl której 100 tys. podpisów należało zebrać w co najmniej siedmiu okręgach wyborczych, w każdym nie więcej niż 15 proc. Wśród ośmiu partii, które musiały wycofać się z kampanii wyborczej, dominowały organizacje mniej lub bardziej opozycyjne wobec prezydenta. Spośród startujących partii i bloków tylko osiem przekroczyło próg wyborczy. ${ }^{3}$ Frekwencja była dość niska $-54,8$ proc. - wyraźnie niższa w porównaniu z elekcją do Zgromadzenia Deputowanych Ludowych RSFSR w 1990 r. (77 proc.). ${ }^{4}$

Wybory do V Dumy (pierwszej po rewolucji lutowej) przyniosły Kremlowi bolesną niespodziankę. Nieoczekiwanie na scenie politycznej pojawiła się nowa i zwycięska siła polityczna - Liberalno-Demokratyczna Partia Rosji (LDPR - 22,9 proc.) i jej lider Władimir Żyrinowski. Proprezydencki „Wybór Rosji” był co prawda drugi (15,5 proc.), ale na plecach czuł oddech rosnących w siłę komunistów Giennadija Ziuganowa (12,4 proc.). Słaby wynik liberałów z „Wyboru Rosji”, któremu komentatorzy polityczni wróżyli absolutne zwycięstwo, był dużą niespodzianką. Okazało się, że reformy gospodarcze spod znaku Jegora Gajdara, niosące gwałtowne obniżenie poziomu życia, znacząco wpłynęły na spadek notowań całego szeroko pojętego obozu reform. Partie demokratyczne nie potrafiły się przy tym zjednoczyć. Nie potrafiły też opracować zwartej i przekonywującej alternatywy programowej dla populistycznych obietnic Żyrinowskiego.

Rzeczywistymi zwycięzcami wyborów z 1993 roku była więc LDPR, ale też Komunistyczna Partia Federacji Rosyjskiej (KPFR). Pierwsza nie tylko potwierdziła, ale też umocniła swoją pozycję na scenie politycznej. ${ }^{5}$ Komuniści natomiast nie tylko zaistnieli parlamentarnie, ale udało im się też skupić dużą część elektoratu nostalgicznego (wobec ZSRR), co w przyszłości miało się okazać stabilnym fundamentem dalszego rozwoju partii. Jedną z ważniejszych przyczyn sukcesu komunistów i nacjonalistów w grudniu 1993 r. stała się aktywna kampania prowadzona w mediach masowych. ${ }^{6}$ Do tej pory Kreml nie potrafił wykorzystać swojej kontroli nad telewizją. W kolejnych wyborach otoczenie Jelcyna starało się nie popełnić już tego błędu.

Istotnym, a w rzeczy samej najważniejszym rezultatem wyborów była faktyczna porażka Jelcyna. Pomimo spacyfikowania parlamentu, ograniczania działań opozycji, manipulacji wyborczych i stworzenia szerokiego, prokremlowskiego

\footnotetext{
3 Część partii i koalicji, które nie zarejestrowały swoich list, wprowadziło do Dumy deputowanych z okręgów jednomandatowych. Dołączyli oni do istniejących frakcji parlamentarnych lub zakładali własne ugrupowania.

4 I. Mikhailovska, Russian voting behavior as a mirror of socjal-political change, „East European Constituional Review" 1996, vol. 5, nr 2-3, s. 57

$5 \quad$ W wyborach prezydenckich w 1991 r. Żyrinowski otrzymał 7,8 proc. głosów.

6 D. Yergin, T. Gustafson, Russia 2010. And What it Means for the World, New York 1994, s. 55.
} 
bloku wyborczego, prezydentowi nie udało się odnieść sukcesu - nie tylko na miarę oczekiwań, ale nawet w stopniu, który umożliwiałby spokojne funkcjonowanie rządu Wiktora Czernomyrdina. Sytuacja mogła być nawet trudniejsza. Na miejscu anarchicznej, rozdartej personalnymi ambicjami i w gruncie rzeczy pozbawionej moralnej legitymizacji opozycji, ${ }^{7}$ pojawiły się nowe, prężne, zintegrowane i mające pełną demokratyczną legitymizację bloki polityczne, których przywódcy - Żyrinowski i Ziuganow - stali się znaczącymi figurami w walce o przywództwo polityczne. Okazało się, że władza Jelcyna wcale nie musi być tak absolutna, jak można byłoby tego oczekiwać jeszcze pod koniec 1993 roku.

Pomimo oczywistego faktu, że określenie „demokratyczna” w stosunku do V Dumy jest swego rodzaju nadużyciem, pamiętać należy, że miała ona swój bezsprzeczny udział w budowaniu rosyjskiego parlamentaryzmu. Nie można też zapominać o olbrzymiej pracy legislacyjnej tego zgromadzenia, które w czasie swojej krótkiej, dwuletniej kadencji przyjęło 328 ustaw. ${ }^{8}$ Wybory parlamentarne w grudniu 1993 roku były bardzo ważnym krokiem w kierunku tworzenia i porządkowania rosyjskiej sceny politycznej. Były też decydującym elementem warunkującym ukształtowanie się systemu partyjnego. Ugrupowania, które weszły do parlamentu, uzyskały rzeczywisty mandat społeczny, a więc formalne przyzwolenie wyborców na działanie. Uzyskały także stosunkowo dużą dozę niezależności. Trzeba jednak pamiętać, że Rosjanie w swoich decyzjach wyborczych kierowali się bardziej sympatią do konkretnych polityków i reprezentowanych przez nich ideologii niż analizą programów ugrupowań politycznych. ${ }^{9} \mathrm{~W}$ tych warunkach partiom trudno było utrzymać stabilną pozycję w parlamencie.

Kadencja V Dumy została określona na 2 lata. Było to związane z nadzwyczajną sytuacją w państwie późną jesienią 1993 roku i nie w pełni wolnym charakterem elekcji. ${ }^{10}$ Owe dwa lata były więc swoistym okresem przejściowym zarówno dla rosyjskiej demokracji, jak i dla ugrupowań politycznych. W powszechnej opinii dopiero VI Duma Państwowa miała zostać sformowana na drodze pierwszych, w pełni demokratycznych wyborów.

\section{Wybory do Dumy - 17 grudnia 1995 r.}

Decydującym sprawdzianem preferencji wyborczych Rosjan, jak również siły zaplecza polityczno-finansowego potencjalnych kandydatów przed wyborami prezydenckimi 1996 r., były wybory parlamentarne z dnia 17 grudnia 1995 roku. Bardzo różniły się one od elekcji sprzed dwóch lat. Inna była atmosfera polityczna

Jako ciało ustawodawcze o proweniencji sowieckiej.

„Российская газета” 22.11.1995 r.

О.Т. Вите, Центризм в российской политике (Расстановка сил в Государственной думе и вне ee), „Polis” 1994, №4, s. 49.

10

A. Czajowski, Demokratyzacja Rosji w latach 1987-1999, Wrocław 2001, s. 90. 
- Kreml nie był w stanie tak głęboko ingerować w procesy wyborcze. W niespotykanym dotąd stopniu rozkwitło życie polityczne. Jeśli w 1993 r. było około 150 organizacji mających prawne możliwości do udziału w wyborach, to w 1995 roku było ich już 259. ${ }^{11}$ Również stopień przygotowań samych partii do wyborów był dużo lepszy niż w 1993 r.

Dominująca pozycja Kremla umożliwiała jednak stosowanie wielu legalnych i nieformalnych środków, przy pomocy których mógł on realizować swoje cele taktyczne. Stosując złożone metody nacisku, ośrodek prezydencki starał się zjednoczyć ugrupowania deklarujące lojalność, równocześnie osłabiając opozycję. Do jej rozbicia Kreml wykorzystywał głównie konflikty wewnątrzpartyjne. Innym elementem walki politycznej było utrudnianie opozycji dostępu do popularnych mediów publicznych znajdujących się w gestii władz. Kreml stosował także specyficzne metody nacisku, które stanowiły po prostu zawoalowaną formę korumpowania opozycyjnych polityków. Kartą przetargową były w tym przypadku intratne stanowiska w państwowym i prywatnym biznesie.

Zwalczaniu konkurencji politycznej sprzyjało ustawodawstwo wyborcze. Konieczność zebrania przez ugrupowania odpowiedniej liczby podpisów (200tys.), nieodzownych do rejestracji przez Centralną Komisję Wyborczą, niosła za sobą możliwość znacznych manipulacji. Zakwestionowanie 3-5 proc. list z podpisami mogło być bowiem równoznaczne $\mathrm{z}$ wycofaniem całej listy, a co za tym idzie - wykluczeniem danego ugrupowania z gry wyborczej. CKW z powodu uchybień proceduralnych skreśliła m.in. listę „Jabłoka” oraz nacjonalistycznego ruchu „Mocarstwo” b. wiceprezydenta Aleksandra Ruckoja. ,Jabłoko” i „Mocarstwo” odwołały się do Sądu Najwyższego. Z podobnymi odwołaniami zwróciło się kilka innych partii i ugrupowań, których zgłoszeń komisja w ogóle nie przyjęła. Sąd Najwyższy nakazał komisji przyjąć zgłoszenie „Jabłoka”, „Mocarstwa”, Partii Demokratycznej, marksistowskiej „Naszej Przyszłości” oraz nacjonalistycznego bloku „Sobór Ziemski”.

Ostatecznie do elekcji przystąpiło 69 partii i bloków wyborczych, z tym że barierę rejestracji przebyły 43 ugrupowania ${ }^{12}$ (w tym 17 bloków wyborczych), z czego zaledwie cztery przekroczyły próg 5 proc. ${ }^{13}$ Frekwencja wyborcza w elekcji 1995 roku była wysoka - wynosiła 64,4 proc.

Zwycięstwo KPFR (22,3 proc.) nie było zaskoczeniem ani dla polityków, ani dla opinii publicznej. Zaskoczeniem okazała się jedynie skala ich sukcesu w okręgach jednomandatowych. ${ }^{14}$ Tu przewaga komunistów wynikała jednak z rozbicia ugrupowań demokratycznych, których kandydaci uzyskali w sumie (procentowo)

11 Е.В. Березовский, Политическая елита российского обшества на рубежие эпох, Москва 1999, s. 148.

12 Ibidem, s. 148

13 Oprócz frakcji czterech głównych ugrupowań, w Dumie zarejestrowano również: „Agrarną Grupę Deputowanych”, grupę deputowanych „Narodowładztwo” i grupę deputowanych „Regiony Rosyjskie”. 
większe poparcie niż komuniści. Dużą sensacją był słaby wynik prokremlowskiego ugrupowania „Nasz Dom - Rosja” premiera Wiktora Czernomyrdina (10,13 proc.). Słabszy od oczekiwanego wynik uzyskała też LDPR (11,18 proc.), której wyborcy z 1993 r. przerzucili swoje poparcie na KPFR.${ }^{15}$ Demokratyczne ugrupowanie „Jabłoko" uzyskało 6,89 proc. poparcia.

Jewgienij Bieriezowski, poszukując podłoża niemal powszechnej klęski partii i bloków wyborczych w elekcji z dnia 17 grudnia 1995 roku, wskazywał na zawyżoną samoocenę partii, a także ich liderów, którzy stanowczo przeceniali swą popularność w społeczeństwie. Skutkiem tego było przyjęcie złej strategii wyborczej, a w konsekwencji porażka. Inną przyczyną była „nieperspektywiczność” stricte wyborczych zjednoczeń i bloków, których istnienie wynikało ze słabości partii politycznych. ${ }^{16}$ Przyczyn porażki demokratów można natomiast doszukiwać się w zniechęceniu społeczeństwa do ugrupowań i polityków oskarżanych o spowodowanie kryzysu gospodarczo-politycznego w Rosji, a także brak umiejętności zbudowania jednolitego bloku, zdolnego do przeciwstawienia się komunistom.

Kampania wyborcza do VI Dumy była znakomitą szkołą marketingu politycznego, sondażem rozkładu społecznego poparcia i motywów wyborów politycznych społeczeństwa. Wybory z 1995 roku znacznie zwiększyły rolę partii w życiu politycznym. Okres ten można nawet określić jako apogeum rosyjskiej wielopartyjności. Okazało się przy tym, że (podobnie jak w Polsce) środek ciężkości życia politycznego zaczął przenosić się z jednorodnych partii politycznych na bloki wyborcze.

Z elekcji parlamentarnej w $1995 \mathrm{r}$. wyłonił się przejrzysty układ sił przed wyborami prezydenckimi. Jasne stało się, że do drugiej tury wyborów przejdzie lider komunistów Ziuganow. Zmobilizowało to wszystkie siły bojące się powrotu starej nomenklatury. Jasne stało się również to, że w drugiej turze Ziuganowa nie pokona ani Jawliński, ani Czernomyrdin. Stąd też jedynym kandydatem sił antykomunistycznych na fotel prezydenta mógł być tylko Jelcyn. ${ }^{17}$

\section{Wybory do Dumy - 19 grudnia 1999 r.}

Wybory w grudniu 1999 r. znacznie różniły się od poprzednich elekcji. Przede wszystkim po raz pierwszy, na tak wielką skalę, prowadzono kampanię za pośrednictwem telewizji - jedynego źródła informacji docierającego niemal do wszystkich potencjalnych wyborców. Interesującym elementem wyborów był również fakt, że sympatie mediów podzieliły się w zasadzie równo pomiędzy dwa nowe bloki: „Ojczyznę - Całą Rosję" (O - CR) - wspieraną przez byłego premiera Jewgienija Primakowa i mera Moskwy Jurija Łużkowa oraz prokremlowski blok „Jedność” pod

\footnotetext{
15 В. Шейнис, Пройден ли исторический рубеж?, „Polis” 1997, nr 1, s. 85.

16 Е.В. Березовский, Политическая елита..., op. cit., s. 158.

17 Е. Охотский, Л. Шмарковский, Выборы-95: три дня и после, „Власть” 1996, nr 2, s. 59.
} 
przewodnictwem Siergieja Szojgu. Stawką w tej rywalizacji było jednak nie tyle zwycięstwo w wyborach do Dumy, co walka o przejęcie politycznej schedy po Jelcynie. Rzeczywisty cel zabiegów wyborczych wyraźnie ujawnił się w kampanii, która koncentrowała się raczej na promocji poszczególnych liderów niż samych partii politycznych. Oba bloki były na tyle pochłonięte walką, że dobrowolnie i z rozmysłem oddały wolną rękę komunistom, którzy zaakceptowali swoją rolę opozycji i nie rościli już żadnych pretensji do władzy. Do kampanii wyborczej włączyła się natomiast Centralna Komisja Wyborcza, wydając szereg niezrozumiałych decyzji, np. odmawiając rejestracji LDPR Żyrinowskiego. ${ }^{18}$

Do grudniowych wyborów stanęło 26 partii i bloków wyborczych, z których jedynie sześciu udało się wprowadzić swoich deputowanych do Dumy. Komuniści zdecydowanie wygrali wybory (24,29 proc.), jednak najsilniejszą grupę w Dumie stanowili deputowani niezależni. Z pewnością dużym zaskoczeniem wyborów był sukces bloku „Sojuszu Sił Prawicowych” byłego premiera Siergieja Kirijenki (8,5 proc.) oraz totalna klęska potężnego niegdyś ugrupowania ND - R Wiktora Czernomyrdina (1,2 proc.). Nie była natomiast zaskoczeniem porażka „Bloku Żyrinowskiego" ( 6,0 proc.). Na taki wynik wpłynęła degradacja moralna partii postrzeganej w społeczeństwie jako najbardziej sprzedajne ugrupowanie w VI Dumie. Okazało się, że na dłuższą metę nie można pogodzić wasalizmu i udawanej opozycyjności wobec władzy. Kolejnym ugrupowaniem, którego wynik wyborczy znacząco minął się z oczekiwaniami liderów, było „Jabłoko”. Partia Jawlińskiego zachowała, co prawda niemal niezmieniony (w stosunku do poprzednich wyborów) poziom poparcia (5,93 proc. w 1999 r. wobec 6,89 proc. w 1995 r.), jednak wynik uzyskany w okręgach jednomandatowych, a także utrata większości w „mateczniku” „Jabłoka” - Petersburgu, wskazywały na regres sympatii wobec tego ugrupowania.

$\mathrm{Z}$ pewnością największą sensacją grudniowych wyborów był relatywnie słaby wynik bloku „Ojczyzna - Cała Rosja” (13,3 proc.) - jeszcze jesienią 1999 r. niemal pewnego kandydata do zwycięstwa. Okazało się, że program budowany wyłącznie na ,antyjelcynizmie” był zbyt słabą podstawą do osiągnięcia sukcesu. O - CR parła do władzy, nie proponując żadnego zwartego programu czy alternatywnej dla Kremla ideologii. Potencjalnych wyborców mogła także zniechęcić „militarna” retoryka liderów ugrupowania, którzy wybierali się na „,wojnę z Jelcynem”. ${ }^{19}$

Prawdziwym zwycięzcą wyborów parlamentarnych został prokremlowski blok „Jedność” (23,3 proc.). Sukces ugrupowania był zapowiedzią zwycięstwa wyborczego Władimira Putina w wyborach prezydenckich w 2000 r. Program wyborczy tego ugrupowania został zastąpiony strategią wyborczą, która opierała się na kilku podstawowych przesłankach. Po pierwsze, kampania została oparta na stale rosną-

\footnotetext{
1813 grudnia 1999 r. Komisja orzekła, że partia może brać udział w wyborach, ale wykluczyła z niej samego Żyrinowskiego. A. Łabuszewska, Spiskowa teoria imitowania demokracji, ,Tygodnik Powszechny” 1999, nr 51-52.

19 Sformułowanie użyte przez szefa sztabu wyborczego O-CR Gieorgija Boosa w wywiadzie dla „Niezawisimoj gaziety" z dnia 21.08.1999 r.
} 
cej popularności premiera Putina, któremu Rosjanie dali in blanco pokaźny kredyt zaufania. Po drugie, sztabowcy „Jedności” przeprowadzili zmasowany atak personalny na liderów głównego konkurenta do władzy - O - CR. Po trzecie, liderom „Jedności” udało się zagrać na tęsknocie wyborców za silnym państwem (zarówno wewnętrznie, jak i na arenie międzynarodowej). I po czwarte, „Jedność” w swojej kampanii wyborczej obficie korzystała ze środków i zasobów państwa. ${ }^{20}$

\section{Wybory do Dumy - 7 grudnia 2003 r.}

Wybory do Dumy w grudniu 2003 roku były pierwszą elekcją, w której zwycięzca - prokremlowska „Jedna Rosja” - był znany jeszcze przed rozpoczęciem głosowania. Niewiadomą pozostawała tyko przewaga tego ugrupowania nad resztą stawki. Kreml przygotował się do rozgrywki bardzo starannie. Szczególne miejsce zajęło w nich nowe określenie instytucjonalnych ról elementów systemu politycznego. W pierwszym rzędzie podjęto próbę ponownego określenia roli ugrupowań politycznych w systemie. Nowa ustawa O partiach politycznych, która weszła w życie w dniu 11 lipca 2001 roku wyraźnie faworyzowała partie duże i silne. Tym samym marginalizowano potencjalną możliwość zaistnienia nowych, krytycznych wobec prezydenta ugrupowań politycznych. W świetle nowej ustawy założenie partii stało się bardzo trudne. Ustawa zakłada także okresową kontrolę zarejestrowanych już organizacji i utratę przez nie statusu partii, w razie gdyby przestały spełniać określone prawem warunki. Według danych ministerstwa sprawiedliwości w dniu 15 lutego 2002 roku w Rosji legalnie funkcjonowało zaledwie siedem partii politycznych. ${ }^{21}$ Innym elementem reformy, mającym na celu eliminację z życia politycznego drobnych ugrupowań, stało się podniesienie progu wyborczego do 7 proc. (przepis obowiązywał od wyborów 2007 r.), a także zwiększenie uprawnień Centralnej Komisji Wyborczej, która otrzymała prawo anulowania wyników ogłoszonych przez komisje regionalne.

W wyborach parlamentarnych w 2003 roku proprezydencka „Jedna Rosja” i związana z rządzącym obozem "Rodina” osiągnęły przytłaczające zwycięstwo (37,57 proc. i 9,02 proc.). Nie było to zaskoczeniem, zważywszy na zmasowaną kampanię i niemal całkowite kontrolowanie mediów przez Kreml lub związanych z reżimem „oligarchów”. Najbardziej wyraziste ugrupowania opozycji, tj. „Jabłoko” i "SPS”, nie przekroczyły progu wyborczego - uzyskało po ok. 4 proc. poparcia i tym samym zostały wyeliminowane z dalszej gry politycznej. Na ile klęska demokratów była spowodowana ich rozbiciem i błędami programowymi, na ile zaś dzia-

20 To, że wszystkie siły państwa rzucone zostały na pomoc wirtualnemu blokowi „Jedność”, zauważył M. Deliagin, Czy nowy autorytaryzm rosyjski może okazać się skuteczny, (w:) A. Madziak-Miszewska (red.), Rosja 2000. Koniec i początek epoki?, Warszawa 2000, s. 58.

21 C. Заславский, Закон о политических партиях принят. Что дальше?, „Конституционное право: восточноевропейское обозрение" 2002, nr 1 (38), 2002, nr 38, s. 17. 
łaniami Kremla, trudno wyrokować, faktem jest jednak, że siła opozycji i tak bardzo niewielka uległa krańcowemu osłabieniu. Pozostałe partie quasi-opozycji, tj. KPFR i LDPR uzyskały poparcie na miarę swych możliwości (12,61 proc. i 11,45 proc.). Gwarantowało im to obecność w parlamencie, ale bez żadnej możliwości wpływania na proces stanowienia prawa. Komuniści i LDPR zostały bardzo osłabione przez sprytny manewr Kremla, z którego inspiracji w 2003 r., a więc przed wyborami, powstało nowe, narodowo-patriotyczne ugrupowanie „Rodina” (założone przez D. Rogozina), odbierające elektorat właśnie KPFR i LDPR.

Wybory z 2003 r. były monitorowane przez ok. 1200 obserwatorów zagranicznych. Zostały one określona jako „wolne, lecz nieuczciwe”. Przedstawiciel delegacji OBWE George Bruce powiedział, że ,nie zostało spełnionych wiele zobowiązań OBWE i Rady Europy, jak również wiele standardów wolnych i demokratycznych wyborów". ${ }^{22}$ Wśród najczęstszych zarzutów wymieniano problemy z tajnością głosowania oraz stronniczość w telewizji publicznej na korzyść „Jednej Rosji”.

\section{Wybory do Dumy - 2 grudnia 2007 r.}

Wybory w grudniu 2007 r. były pierwszą elekcją odbywającą się według nowej, uchwalonej w kwietniu 2005 roku ordynacji wyborczej, która podnosiła próg wyborczy z 5 do 7 proc. To w połączeniu z zakazem łączenia się partii w wyborcze bloki uderzało w mniejsze partie opozycyjne, które nie miały praktycznie szans na zdobycie wymaganego poparcia. Jeszcze groźniejszą bronią przeciwko opozycji stało się jednak zlikwidowanie okręgów jednomandatowych, w których partie demokratyczne tradycyjnie zdobywały przynajmniej po kilka mandatów. Wyeliminowało to możliwość elekcji polityków niezależnych od reżimu, reprezentujących regiony, biznes, a przede wszystkim środowiska demokratyczne. ${ }^{23}$ Zniesiono próg minimalnej frekwencji, wymaganej do uznania wyborów za ważne. Zlikwidowano też możliwość głosowania „przeciwko wszystkim”. Aby uzyskać rejestrację w CKW partie zostały zobowiązane do zebrania co najmniej 200 tys. podpisów wyborców pod listą kandydatów lub do wpłacenia kaucji w wysokości $60 \mathrm{mln}$ rubli $(2,35 \mathrm{mln}$ dolarów). Zwrot kaucji miał nastąpić po wyborach, ale tylko wobec partii, które uzyskały nie mniej niż 4 proc. głosów. Partie reprezentowane w Dumie - „Jedna Rosja”, „Sprawiedliwa Rosja”, Komunistyczna Partia Federacji Rosyjskiej i Liberalno-Demokratyczna Partia Rosji zostały zwolnione z obowiązku zbierania podpisów lub wpłacania kaucji. Symptomatycznym gestem wykonanym przez Kreml, który wskazywał na fakt, że rozstrzygnięcia polityczne zapadły już przed wyborami i były niezależne od głosów wyborców było drastyczne ograniczenie obserwatorów OBWE z 400 (w 2003 r.) do zaledwie 70 w 2007 r. 
Najsilniejszą partią na rosyjskiej scenie politycznej przed wyborami w $2007 \mathrm{r}$. była prokremlowska „partia władzy” - „Jedna Rosja”. Pewną rolę w dalszym ciągu odgrywały KPFR oraz LDPR - te dwa ugrupowania faktycznie pogodziły się jednak z rolą limitowanej opozycji i nie stanowiły dla Kremla żadnej alternatywy. $\mathrm{Z}$ istotnych ugrupowań politycznych można jeszcze wymienić drugą ,partię władzy“ - „Sprawiedliwą Rosję”. Partie opozycyjne: Rosyjski Sojusz Ludowo-Demokratyczny byłego premiera M. Kasjanowa, Republikańska Partia Rosji W. Ryżkowa, Zjednoczony Front Obywatelski G. Kasparowa, Partia Narodowo-Bolszewicka E. Limonowa - wszystkie zjednoczone w ugrupowaniu „Inna Rosja” oraz „Jabłoko" G. Jawlińskiego, od początku wskazywane były jako ofiary 7-proc. progu wyborczego. W przypadku niektórych partii CKW nie dała nawet szansy startu w wyborach kwestionując listy poparcia. Wykluczono m.in. Sojusz Ludowo-Demokratyczny, Zjednoczony Front Obywatelski, Republikańską Partię Rosji, „Wielką Rosję" D. Rogozina i Partię Narodowo-Bolszewicką. Do udziału w wyborach dopuszczono ostatecznie 11 partii.

Kampania wyborcza do parlamentu była farsą. Rosyjska telewizja w debatach pomija udział przedstawicieli partii opozycyjnych. Przeciętny Rosjanin był stale epatowany propagandą Kremla i prokremlowskiej „Jednej Rosji”. Ostatecznie „Jedna Rosja” otrzymała 64,3 proc. głosów, KPFR - 11,57 proc., LDPR - 8,14 proc. i „Sprawiedliwa Rosja” - 7,74 proc. Pozostałe ugrupowania nie przekroczyły progu wyborczego. $^{24}$

Z partii, które dostały się do parlamentu najbardziej zawiedzeni wynikiem byli komuniści, którzy nawet zaskarżyli wynik wyborów. Pozaparlamentarna opozycja ostro, aczkolwiek bezskutecznie głosiła, że były to najmniej uczciwe wybory w historii Rosji. Potwierdzali to Obserwatorzy Zgromadzenia Parlamentarnego OBWE i Zgromadzenia Parlamentarnego Rady Europy.

W wyborach z 2007 r. zwraca uwage gwałtowny, prawie 10-procentowy skok frekwencji w stosunku do wyborów z $2003 \mathrm{r}$. - tj. 63,72 proc. W pewnym stopniu mógł być on wynikiem dokonanej przez Kreml masowej mobilizacji społeczeństwa, być może jednak - chociaż to tylko spekulacje - był on rezultatem fałszerstw wyborczych.

\section{Wybory do Dumy - 4 grudnia 2011 r.}

Wybory, które odbyły się na przełomie 2011/2012 roku dość niespodziewanie pokazały, że rosyjski quasi-autorytaryzm wpadł w swoistą „pułapkę” demokracji. Okazało się, że propaganda, socjotechnika i manipulacja nie mogą całkowicie zastąpić polityki i rosnących aspiracji Rosjan. Względna stabilizacja ekonomiczna, którą zapewniły rządy Putina w sposób naturalny zaowocowała oczekiwaniami politycz- 
nymi wyrażanymi głównie przez rosyjską młodzież (która często nie pamięta już chaosu czasów Jelcyna) i klasę średnią. Formułowane przez „tymczasowego prezydenta" - Dmitrija Miedwiediewa - hasła modernizacji demokratyzacji okazały się pustosłowiem. Zwłaszcza w zderzeniu $\mathrm{z}$ rzeczywistością. W grudniowych wyborach parlamentarnych zwyciężyła „Jedna Rosja”, która uzyskała 49,5 proc. głosów, następne były KPFR - 19,2 proc., „Sprawiedliwa Rosja” - 13,2 proc. i LDPR - 11,7 proc. Progu wyborczego nie przekroczyła partia „Jabłoko” - 3,3 proc. Ugrupowanie opozycji antyrządowej - „Parnas” (Partia Wolności Narodowej) - nie zostało dopuszczone do wyborów. ${ }^{25}$ Ministerstwo Sprawiedliwości Rosji jeszcze we wrześniu 2011 r. odmówiło wpisania tego ugrupowania do rejestru partii politycznych. W uzasadnieniu resort sprawiedliwości oświadczył, że statut ugrupowania zawiera zapisy sprzeczne z ustawą o partiach politycznych i innymi federalnymi aktami prawnymi. ${ }^{26}$

Rezultat wyborów parlamentarnych był zaskakujący i dość niejednoznaczny. „Jedna Rosja” zdecydowanie wygrała, jednak osiągnęła wynik znacząco słabszy niż w wyborach w 2007 r. Niejednoznaczność tego rezultatu wynikała, rzecz jasna, z licznych fałszerstw, których dopuszczono się na korzyść „Jednej Rosji”, ale też $z$ faktu, że w reżimie niedemokratycznym rządząca partia osiąga wynik daleko niesatysfakcjonujący dla rządzących. Wykryte fałszerstwa były często tak nachalne, że można przypuszczać, że nie były one wynikiem polecenia z Kremla, a „inicjatywą oddolną" miejscowych działaczy, którzy chcieli wykazać sukces swojej „pracy partyjnej" w terenie. Być może wybory w Rosji były plebiscytem preferencji politycznych przed wyborami prezydenckimi, próbą wysondowania rzeczywistego poparcia władzy przed kluczowymi rozstrzygnięciami? Jeśli tak było, to rządząca oligarchia poniosła porażkę. Nie chodzi tu zresztą o sam wynik głosowania, ale o powszechne wśród Rosjan przekonanie, że wybory zostały sfałszowane. Ostatecznie podważyło to i tak coraz bardziej wątpliwą demokratyczną legitymację władzy.

Wybory parlamentarne z $2011 \mathrm{r}$. to powrót na scenę polityczną opozycji, która jak się okazało ma jednak znaczny posłuch w społeczeństwie i to pomimo blokady informacyjnej w prorządowych mediach. Aktywni byli Garri Kasparow, który zachęcał do bojkotowania wyborów, Boris Niemcow - nawoływał do skreślania całych kart wyborczych, czy znany bloger Aleksiej Nawalnyj - wzywał do oddania głosu na każdą partię z wyjątkiem ,Jednej Rosji”. Ich głos docierał jednak głównie do mieszkańców dużych miast, często za pośrednictwem Internetu, którego władzy nie udało się dostatecznie kontrolować. Rola Internetu, w tym Social Media okazała się kluczowa. Przede wszystkim był to kanał pozwalający na sprawne organizowanie się protestujących (za pomocą Facebooka, Twittera i VK), a także oszacowanie cje/analizy/2011-12-07/wybory-parlamentarne-w-rosji-powrot-polityki (data dostępu: 21.12.2014 r.). 26 Partię utworzyli w 2010 roku czterej liderzy opozycji demokratycznej: Michaił Kasjanow, Władimir Miłow, Borys
Niemcow i Władimir Ryżkow. 
poparcia. Istotne były też powszechne, negatywne komentarze na temat urzędującego premiera (Putina). Internet pozwolił jednak przede wszystkim na szybkie ujawnienie przypadków fałszerstw wyborczych. Rosjanie kręcili filmy i robili zdjęcia dokumentujące przebieg głosowania, a następnie umieszczali je w sieci.

Aktywizacja opozycji była funkcją wielkiego, nie notowanego w Rosji od kilkunastu lat, poruszenia społecznego. W dniach 5 i 6 grudnia na ulicach wielu miast Rosji odbyły się protesty przeciwko sfałszowaniu wyborów. Najliczniejszy wiec w Moskwie, który odbył się w dniu 5 grudnia zgromadził od 5 do 8 tys. osób. ${ }^{27}$ Przez kilka tygodni mogło się nawet wydawać, że reżim w Moskwie zaleje fala „kolorowej rewolucji”, zwłaszcza że do protestów przyłączyli się działacze opozycji parlamentarnej, próbujący przy pomocy społeczeństwa poprawić swoją pozycję w relacjach z Kremlem. Skala sprzeciwu społecznego zmusiła władze do pewnych ustępstw na rzecz protestujących. Zapowiedziano liberalizację prawa wyborczego. Prezydent Miedwiediew wygłosił też ogólnikowe deklaracje dotyczące przywrócenia bezpośrednich wyborów gubernatorów oraz zwiększenia pluralizmu w mediach. Tak naprawdę nie podjęto jednak realnego dialogu z protestującymi. Zamiast niego władze prowadziły zakrojoną na szeroką skalę akcję dyskredytacji opozycji i sprowokowania rozłamów w jej szeregach.

\section{Zakończenie}

Proceduralna strona demokracji w jej liberalnym wariancie traktuje wybory jako prawomocne delegowanie uprawnień władczych, to zaś jest sprzeczne z historycznym pojmowaniem władzy w Rosji - zarówno przez reżim polityczny, jak i społeczeństwo. ${ }^{28}$ Co więcej, sama instytucja wyborów nie utrwaliła w Rosji rozróżnienia między „suwerenem” i ,władzą". Takie postrzeganie tego problemu było (i jest) wygodne w pierwszym rzędzie dla grupy pozostającej przy władzy, która mogła w ten sposób tłumaczyć swoje niedemokratyczne działania.

Klęska w sporze konstytucyjnym w latach 1992-1993, jak również w sprawie procedury impeachmentu Jelcyna w 1998 r. sprawiły, że władza ustawodawcza coraz bardziej zmierzała w stronę fasadowości, stając się jedynie listkiem figowym prezydenckiego autorytaryzmu. Reżim prezydencki pozbawił parlament samodzielności, pozwalając mu na działanie, jednak raczej w sferach niekonfrontacyjnych dla władzy. Funkcje parlamentu zostały drastycznie ograniczone już w wyniku przyjęcia konstytucji z 1993 r. Dumie pozostawiono wprawdzie najważniejszą z nich - funkcję ustawodawczą, jednak realne przesunięcie inicjatywy ustawodawczej do prezydenta i rządu powodowało, że niezależność parlamentu w tej kwestii była co najmniej dys- 
kusyjna. W jeszcze większym stopniu dotyczyło to funkcji ustrojotwórczej, którą po 1993 roku parlament faktycznie utracił na rzecz prezydenta. Wydaje się też, że rosyjski parlament nie integrował i nie socjalizował wspólnoty politycznej, ponieważ miał zbyt małe ku temu możliwości i przede wszystkim zbyt mały autorytet. Elementem scalającym system i socjalizującym wspólnotę polityczną był tu bez wątpienia prezydent i współpracujące z nim elementy układu władzy. Podobnie rzecz się miała, jeśli idzie o udział parlamentu w formowaniu rządu. Znacznym utrudnieniem dla antyprezydenckich działań Dumy była też postawa Rady Federacji, która z reguły popierała działania prezydenta (była raczej stałym sojusznikiem Kremla), a tym samym jeszcze bardziej ograniczała samodzielne działania izby niższej.

Wybory parlamentarne po 1999 r. wyraźnie wskazywały, że polityczna rola opozycji parlamentarnej stopniowo dobiega końca. Reżim nie zdecydował się jednak na bezpośrednie, niedemokratyczne działania wobec niepokornych deputowanych. Stopniowe ograniczanie opozycji poprzez odbieranie jej zasobów politycznych (,przejmowanie” poszczególnych liderów opozycji) i ekonomicznych było jednak aż nazbyt widoczne. Szykany nie dotykały bezpośrednio polityków i partii, ale ludzi im pomagających czy finansujących. Ostateczne odcięcie opozycji od większości środków masowej informacji spowodowało, że reżim mógł niemal dowolnie manipulować wyborami, a co za tym idzie, sceną polityczną, faktycznie rugując z życia politycznego te ugrupowania, których opozycyjność była dla Kremla szczególnie kłopotliwa. Wybory parlamentarne w 2003 r., w których doszło do faktycznego wyeliminowania antykremlowskiej opozycji, potwierdziły tylko zarysowaną wcześniej tendencję. Te partie, które pozostały na scenie politycznej, zmuszone zostały do zaakceptowania swojej kontrolowanej opozycyjności. Wybory w 2007 r. i 2011 r. to już tylko imitacja demokracji ze strony Kremla. Ostateczne wyeliminowanie realnej opozycji parlamentarnej przywróciło jednak funkcjonalną równowagę systemu politycznego, opartą na rzeczywistej nierównowadze poszczególnych jego elementów, tj. na absolutnej dominacji Kremla, czy też „politycznej korporacji” rządzącej Rosją.

Ogólny poziom wolności w czasach Putina uległ znaczącemu zmniejszeniu w porównaniu z okresem, ,jelcynizmu". Co więcej, wydaje się, że proces ten ma duże szanse na dalszą intensyfikację. Pierwszy okres prezydentury Putina (20002008) przygotował grunt pod głębszy autorytaryzm. Jego rozprzestrzenianie niewątpliwie stymuluje reżim polityczny, obficie korzystający w tym zakresie z zasobów władzy. Rosyjski system polityczny nadal zawiera w sobie jednak elementy konkurencyjnej oligarchii, zachował mechanizm demokratycznej legitymizacji w sensie formalnym (wybory) i nieformalnym (kontrakt) oraz elementy liberalizmu gospodarczego. Ponadto w Rosji pewną rolę odgrywa klasa średnia, która chociaż związana z państwem, to jednak jest bardziej niezależna i przede wszystkim liczniejsza niż np. na Białorusi. Mniejsza wydaje się więc polityczna rola „marginałów”, jako bazy politycznej autorytaryzmu. 


\section{BIBLIOGRAFIA}

Березовский Е.В., Политическая елита российского обшества на рубежие эпох, Москва 1999

Czajowski A., Demokratyzacja Rosji w latach 1987-1999, Wrocław 2001

Steven Fish M., Democracy Derailed in Russia: The Failure of Open Politics, Cambridge University Press 2005

Marciniak W., Rozgrabione imperium. Upadek Związku Sowieckiego i powstanie Federacji Rosyjskiej

McFaul M., Russia's Unfinished Revolution: Political Change from Gorbachev to Putin, Cornell University Press, 2001

Пути российского посткоммунизма, под ред. М. Липман и А. Рябова, Моск. Центр Карнеги, М. 2007

Rogoża. J.: Wybory parlamentarne w Rosji: powrót polityki, Warszawa 07.12.2011, Ośrodek Studiów Wschodnich

Rosja 2000. Koniec i początek epoki?, A. Madziak-Miszewska (red.), Warszawa 2000

Rosefielde S., Russia in the 21st Century: The Prodigal Superpower, Cambridge University Press 2005

Россия политическая, ред. Л. Шевцова; Моск. Центр Карнеги, М.: РОССПЭН, 1998

Шевцова Л., Режим Бориса Ельцина, Моск. Центр Карнеги, М.: РОССПЭН, 1999.

Sakwa R., Putin: Russia's Choice, NY 2004

Skrzypek A, Putinada. Rosja - kraj kierowanej demokracji, Warszawa 2014.

Shevtova L., Puins Russia, CarnegieEndowment for International Peace, Waszyngton 2003

Шевцова Л., Режим Бориса Ельцина, Моск. Центр Карнеги, М.: РОССПЭН, 1999 
ELECTIONS TO THE STATE DUMA OF RUSSIAN FEDERATION 1993-2011

Subsequent to December 1993, when the first elections were held for the newly formed Russian parliament, five further parliamentary election processes have been conducted. These occurred in the years 1995, 1999, 2003, 2007 and 2011. With the exception of the 1995 and 1999 elections, all were far from being of free and democratic character. In particular the 2007 election constituted a political farce with its outcome predetermined. Among others, the weaknesses of the system relate to a lack of parliamentary tradition in Russia, constitutional and legal solutions that favour the president, and the absence of developed and stable party structures.

Keywords: Duma, elections, Russia, Yeltsin, Putin

Słowa kluczowe: Duma, wybory, Rosja, Jelcyn, Putin 